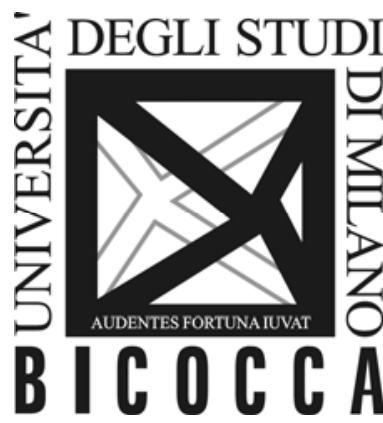

DEPARTMENT OF ECONOMICS

UNIVERSITY OF MILAN - BICOCCA

WORKING PAPER SERIES

\title{
Dissecting Chinese ODI: Dragon Multinationals in Italy
}

Valeria Gattai

No. 175 - December 2009

Dipartimento di Economia Politica

Università degli Studi di Milano - Bicocca

http://dipeco.economia.unimib.it 


\title{
Dissecting Chinese ODI: Dragon Multinationals in Italy
}

\author{
Valeria Gattai
}

\begin{abstract}
This paper provides original evidence about Chinese Outward Direct Investments in Italy. Data have been collected at the micro level, through a multiple-choice questionnaire, designed by the author and submitted to the whole population of Dragon multinationals. With a reply rate of $65 \%$, we draw a detailed profile of Chinese parent companies and document the strategic features of their operations in Italy. Empirical findings are highly consistent with the theoretical expectations.
\end{abstract}

JEL code: F23, O53

Keywords: Outward Direct Investment, Dragon multinationals, China, Italy

\footnotetext{
* The author is grateful to Gianmarco Ottaviano and Roberta Rabellotti for useful comments and insightful discussions, and Francesca Ghezzi and Valentina Zanatta for valuable assistance in data collection. This paper is part of the project "Chinese Investments in Europe". Financial support from CASCC and Chatham House is gratefully acknowledged. All remaining errors are the author's own.
} 


\section{Introduction}

The past two decades have witnessed the rise of a growing number of Multinational Enterprises (MNEs) from emerging economies, mainly because of overseas expansion by Asian companies (UNCTAD 2007, 2006).

Outward Direct Investment (ODI) from developing countries is not a new phenomenon, but it has recently experienced both a quantitative and a qualitative transformation. On the one hand, the magnitude of investments has markedly increased over time. According to UNCTAD (2008), flows of ODI rose from 6 to 253 billion USD and stocks moved from 145 to 2,288 billion USD, between 1990 and 2007. On the other hand, the geographical and sector patterns have changed as well, shifting from developing to developed countries as a host and from manufacturing to the service industry as a target.

China, in particular, has consolidated its position as a global investor, moving from virtually zero ODI in 1978 to the record stock of 96 billion USD in 2007. With an average growth rate of $60 \%$ between 2002 and 2006, China ranked thirteenth among largest source countries worldwide in 2007 (Cui et al. 2008) and sixth among emerging economies (UNCTAD 2008). To mention just a few examples, the Lenovo Group, China's largest computer manufacturer, successfully acquired the global PC business of IMB in 2004. At the same time Haier, the famous Chinese household appliances company, established its manufacturing plants in South Carolina; TLC bought the television arm of France's Thomson SA and Alcatel SA, and Nanjin Automotive Industry Corporation acquired MG Rover to set production facilities in the UK.

This evidence crucially challenges the old view of the country as a low cost manufacturing location: even though China has been traditionally considered as a magnet for Foreign Direct Investment (FDI), nowadays it is increasingly becoming a source of multinational activity (Schuller and Turner 2005).

Notice that the internationalization process involving Dragon multinationals represents a recent chapter in China's long history. In fact, it is only since the instigation of the "Open Door" policy in 1978, that the country has experienced deep economic reforms, to change the domestic industrial structure and increase its integration into the global economy. Hence, during the last three decades, China has been able to amaze global observers through a number of record performances, from steady economic growth to FDI attraction, from trade expansion to the emergence of a large and relatively affluent middle class. However, the aspect of China rising power that is most noticed nowadays is the dramatic growth of its outward direct investment. Under the "Go Global” policy, advocated in 2002, restrictions to outflows are lowered and government efforts to promote international expansion are stepped up, thus China's role as a major investor is expected to keep on growing in the future ${ }^{1}$.

While many papers have been investigating the strategic drivers behind the internationalization patterns of Dragon multinationals, most research remains descriptive and empirical evidence is rather scattered. In particular, when quantitative analysis is provided, it is mostly based on macroeconomic data to

\footnotetext{
${ }^{1}$ For more details about the historical process of Chinese internationalization, see (OECD 2008; Zhang Y. 2005; Warner et al. 2004; Cai 1999; Tseng 1994). The role of the State in promoting outward direct investments and the main actors involved at the political level, are exhaustively investigated by (Berger and Berkofsky 2009; Buckley et al. 2008b; Poncet 2007).
} 
make a general overview of sector and geographical patterns (see, for instance: Nicolas and Thomsen 2008; Rabellotti and Sanfilippo 2008; Gao 2008; Poncet 2007; UNCTAD 2006; Schuller and Turner 2005). This kind of studies, however, fails to explain what is behind those trends: why do Chinese enterprises invest abroad? What drives their location choice? How do they enter into a foreign market? What kind of returns and problems do they face when operating abroad? To answer these and similar questions, we need to go beyond the macroeconomic evidence and explore the universe of firm-level information. Put another way, we need to dissect Chinese ODI through microeconomic data, to disentangle the singles voices aggregated in the macro chorus.

Notice, however, that quantitative studies, based on microeconomic data, are quite limited, and they range from cases histories (see, among others: Duysters et al. 2009; Liu 2007; Li 2007) to sector analysis (see, for example: Niosi and Tschang 2009; Kumar and Chadha 2009) or anecdotal evidence (as in: Gao 2008; Zhang Y. 2005; Deng 2004). To best of our knowledge, survey data about Chinese ODI at the micro level, has not been systematically collected yet, preventing the dissection of general trends ${ }^{2}$.

To fill this gap, the present paper aims at providing original evidence about Dragon multinationals in Italy, building on a multiple-choice questionnaire designed by the author and submitted to the whole population of Chinese affiliates in this country. We select Italy, as a host market, due to its relevance among European countries. As Table 1 suggests (see Section 3), Italy has attracted an increasing amount of Chinese ODI from 2005, reaching a stock value of 82 million USD in 2007; as a result, it now ranks fifth among European recipients. With a reply rate of $65 \%$, the present paper outlines the quantitative and qualitative features of 20 direct investments, corresponding to 49 operating plants, disseminated throughout the Italian market. To the best of our knowledge, this is the first attempt at collecting survey data about Chinese ODI, offering such an exhaustive framework, both in terms of sample representativeness and topic coverage. Despite the high reply rate, the limited number of observations prevents us from conducting a proper econometric exercise; however, a number of summary statistics and figures are provided to summarize the main findings of the survey. We believe this is a first step in analysing Chinese ODI at the micro level to dissect macro trends with firmlevel details.

The rest of the paper is organized as follows. Section 2 provides a brief literature review that serves as a theoretical framework for the empirical analysis. Section 3 presents recent macroeconomic evidence of Chinese ODI, to characterize general trends, while Section 4 focuses on the experience of Dragon MNEs in Italy, based on the survey results. Since the questionnaire is designed according to the existing literature, in commenting the main findings in Section 4, particular attention is

\footnotetext{
${ }^{2} \mathrm{~A}$ few exceptions are due to (Buckley et al. 2008a; Cui et al. 2008; Zhang 2005). Buckley et al. (2008a) captures $17 \%$ of Chinese ODI in the UK by means of a brief questionnaire, focused only on strategic drivers. Cui et al. (2008) complements micro data from the Statistical Bullettin of China's Outward Foreign Direct Investment, through questions about entry mode choices. Zhang (2005) interviews over 200 Chinese enterprises (not necessarily MNEs) to state their potential interest in investing in Canada. The lack of survey data about Chinese ODI is lamented also in (Buckley et al 2007; Filippov and Saebi 2008; Aulakh 2007; OECD 2006).
} 
devoted to the matching between empirical findings and theoretical expectations. Section 5 then concludes and sets future lines of research.

\section{Literature review}

This Section provides a brief literature review about Dragon multinationals ${ }^{3}$. To describe the burgeoning number of contributions belonging to this field of study, two subsections follow. In (2.1), we discuss whether the traditional view of foreign direct investment, elaborated to explain outflows from industrialized countries, is applicable to emerging economies ODI. In (2.2), we summarize the main characteristics of Dragon multinationals and their foreign operations, as depicted in the existing literature. The theoretical framework delineated below is particularly important for the empirical part of this paper since the multiple-choice questionnaire is structured accordingly.

\subsection{Is the traditional view of foreign direct investment capable of explaining new ODI from emerging economies?}

In the last 30 years, the literature on multinational enterprises has fruitfully developed around Dunning's OLI and IDP frameworks, considered as the leading theoretical explanation of why and when FDI occurs (see Dunning 1981, 1993). This is what we call the "traditional" view of foreign direct investment.

The intuition behind Dunning's arguments is quite straightforward. If MNEs were identical to domestic firms, they would not find it profitable to enter the domestic market. Since FDIs indeed exist, it must be the case that multinational firms possess some inherent advantages easily exploitable through direct investment. FDI operations are thus explained as an attempt to capitalize abroad certain Ownership-Location-Internalization (OLI) characteristics, own before internationalization. Ownership advantages correspond to some product, knowhow, reputation or production process to which other firms do not have access. Location advantages arise when it is profitable to produce directly in the domestic market, rather than manufacturing at home and exporting abroad, and Internalization advantages critically shape the boundaries of the firm. Adding to this, Dunning (1993) distinguishes across market-, efficiency- and resourceseeking FDI, where the first is intended to access foreign markets, the second aims at pursuing an efficient specialization of the firm, and the third is motivated by the wish to secure unique natural or strategic ${ }^{4}$ resources, available in the host market. If the OLI framework provides only a static explanation of why FDI occurs, the socalled Investment Development Path (IDP) model complements the previous picture, by adding the dynamics. According to this framework, the net outward investment position of a country is positively associated to its level of economic development, and emerging economies internationalize through various stages. The intuition is that, as a country grows, it becomes attractive for inward FDI and,

\footnotetext{
${ }^{3}$ Notice that some of the papers reviewed in Section 2 refer generically to emerging economies rather than Dragon MNEs. However, since most of emerging economies MNEs originate from China (OECD 2006), they have been included in the present study. In what follows, Dragon, emerging or developing countries MNEs are treated as synonymous. For a survey, see Amighini et al. (2009).

${ }^{4}$ Strategic resources are intangible assets such as technology, human capital and reputation.
} 
through the interaction between domestic and multinational enterprises, it strengthens its location and ownership position. Hence, moving along further stages of development, the country begins to export and, by exploiting internalization advantages, it undertakes outward FDI in economies lower down in the stage of development ${ }^{5}$.

This "traditional" view of foreign direct investment was elaborated to explain FDI patterns from industrialized countries. This is the reason why, in recent years, a growing strand of the literature has begun to question its fit with investment projects coming from emerging economies.

In particular, a first group of authors criticizes Dunning's OLI-IDP approach and calls for a new paradigm. Athreye and Kapur (2009) believe that the OLI theory has only limited power in interpreting the internationalization paths of developing countries MNEs, because they lack exactly the kind of advantages that the theory emphasizes as a prerequisite for investing abroad. As latecomers, Dragon MNEs engage in asset-seeking rather than asset-exploiting FDI (Deng 2007; Luo and Tung 2007). Contrary to the internalization advantage, they often favour partial ownership of the local affiliate (Li 2007), and they expand overseas to address some competitive disadvantages, such as regional protectionism, limited access to capital, lack of intellectual property rights, poor local infrastructures and underprovision of training and education (Child and Rodrigues 2005; Zhang 2005; Boisot 2004; Nolan 2001). A similar argument is due to Buckley et al. (2007), where time series estimates reveal that Dragon multinationals do not respond to the traditional OLI stimulus. More precisely, Chinese ODIs turn out to be positively associated with political risk and cultural proximity, during the entire 1984-2001 period, while they are driven by host market size, natural resource endowment and geographical proximity only in certain years. Consistently with this view, the Linkage-Leverage-Learning (LLL) model, due to Matthews (2006), captures the idea that latecomers MNEs use their overseas investments and global linkages to leverage cost leads and learn about new sources of competitive gains. If so, FDI may contribute to build ownership advantages, rather than merely being an outcome of the existing ones ${ }^{6}$. All contributions reviewed above are characterised by sharp criticism towards the OLI paradigm, but the Investment Development Path model is not free from concerns too. For instance, Athreye and Kapur (2009) and $\mathrm{Li} \mathrm{(2007)}$ find that the time profile of Chinese ODI does not conform to the conventional predictions of the IDP framework. Their empirical evidence shows that Dragon multinationals developed their industrial bases through policies of import substitution, without massive inflows of FDI in the early stages. Moreover,

\footnotetext{
5 In the spirit of the IDP model, Luo and Tung (2007) stress the important linkages between inward and outward FDI. Indeed, what developing countries are nowadays is the result of the amount of resources - capital and technology - acquired through inward flows. If today they are able to engage in outward FDI, this crucially depends on the mass of inward investments received in the past. In this sense, inward and outward flows are complementary, and they both facilitate international experience and intercultural exchange. A similar argument is due to Pack (2001) that explains Taiwan's fast growth through the country's capacity of absorbing foreign resources with inward FDI.

${ }^{6}$ A different opinion is expressed in $\mathrm{Li}$ (2007) where the LLL model is criticized for being ambiguous about the distinction among learning, leverage and linkage. Building on OLI ad LLL, Li (2007) develops a new theory of FDI by merging the internal factors stressed by Dunning with the external ones emphasized by Matthews.
} 
outflows have emerged much sooner than expected, and they are directed primarily towards developed rather than developing hosts. Last, Gao (2008) tests the determinants of Chinese ODI through time series data of the period 1980-2006 and he finds that outward direct investment is not related to economic development, measured by GDP. On the contrary, it is positively associated with overseas network, R\&D investments and inward FDI.

The group of contributions mentioned so far shares the drastic view that Dunning approach is not applicable to emerging countries ODI and therefore it advocates an ad hoc paradigm to account for this phenomenon. However, a second group of papers questions the traditional view of foreign direct investment, but it allows only for a modest reconsideration of it, showing that the old theory can be adapted without the need to build a new one. Through a longitudinal cross-country comparative study of 256 large firms in 1990-2005, Fortanier and Tulder (2009) find that Chinese and Indian multinationals are not a completely new species of firms. Indeed, the OLI mechanism is still at work because Dragon MNEs possess some ownership advantages, even though different from those of developed countries. While investors located in advanced economies rely on technology, brand and intellectual property the most, Dragon multinationals ground their internationalization path on process capabilities (UNCTAD 2006), management and corporate entrepreneurship (Yiu et al. 2007), parental networks (Fortanier and Tulder 2009), flexibility, social and networking skills (Buckley et al. 2007; UNCATD 2006). As a result, a modest change in the OLI-IDP framework might be sufficient to reconcile the traditional theory with the new phenomena.

\subsection{Characteristics of Dragon multinationals and their ODI}

Having discussed the theoretical framework to analyze emerging economies ODI, this sub-section investigates the peculiarities of Dragon multinationals and their investments. Based on (2.1), MNEs from developing countries seem to differ, at least partially, from those located in industrialized economies, hence (2.2) briefly explores the nature of the main differences.

As far as the portrait of the multinational is concerned, the first peculiarity identified in the literature is the high degree of state ownership, which explains the active role played by the government in promoting global expansion (Amighini et al. 2009; Yeung and Liu 2008; Deng 2007; UNCTAD 2006). Moreover, Dragon MNEs usually enjoy a leading global position in industries such as automotives, chemicals, electronics, petroleum refining and steel, transport and telecommunication (UNCTAD 2006). They are relatively small, compared to players from industrialized countries, although a number of large ones with global ambitions have recently appeared on the world stage (Amighini et al. 2009; UNCTAD 2006). They are used at operating in highly volatile environments (Fortanier and Tulder 2009) and they rely of firm-specific advantages such as process capabilities (UNCTAD 2006), management and corporate entrepreneurship (Yiu et al. 2007), parental networks (Fortanier and Tulder 2009), flexibility, social and networking skills (Buckley et al. 2007, UNCATD 2006). While emerging economies MNEs are usually treated as a homogeneous group, a few papers also explore cross-country differences among them. Duysters et al. (2009) compare Tata and Haier to identify key similarities and differences between Chinese and Indian multinationals. They find that firms originating from both 
countries receive notable state support, they are successful in creating new products and accessing new markets and make strategic asset seeking ODI. However, Tata has a much longer history, it cumulated several decades of experience in developing countries before entering into a developed market, and it has a stronger preference towards Merger \& Acquisition (M\&As), compared to Haier. (Niosi and Tschang 2009; Kumar and Chadha 2009) further analyze Chinese and Indian investors, with a focus on the software and steel sector, respectively. They suggest that firms from both countries tend to receive massive government support, and to target culturally similar markets, however, Indian MNEs are usually smaller and private, they enjoy a larger proportion of international sales and show a higher propensity to operate abroad, compared to their Chinese counterparts.

If this is the portrait of Dragon multinationals, what are the characteristics of their investments abroad? What are the push and pull factors? Is there any trend in terms of entry mode choices?

A variety of drivers seems to promote global expansion of emerging countries MNEs. Following Dunning (1993)'s classification of pull factors, market- and resource-seeking FDIs are particularly important, while efficiency considerations play only a limited role (Athreye and Kapur 2009; Fortanier and Tulder 2009; Duysters et al. 2009; Kumar and Chadha 2009; Nicolas 2009; Nicolas and Thomsen 2008; Amighini et al. 2008; Yeung and Liu 2008; UNCTAD 2006; Deng 2004, 2007; Schuller and Turner 2005; Zhang 2005; Wu 2005;). According to (Amighini at al. 2008; Filippov and Saebi 2008), resource-seeking operations have experienced a radical evolution over time: until the 1990s, they were motivated by the hunger for natural resources while technology, brand and human capital are the kind of assets that Dragon MNEs search for nowadays. Adding to pull factors, a variety of push forces are worth mentioning when trying to explain recent flows of ODI. These forces range from government support to competitive pressure, from the availability of capital to over-capacity in the domestic market ${ }^{7}$ (see, among others: Kumar and Chadha 2009; Athreye and Kapur 2009; Duysters et al. 2009; Berger and Berkofsky 2009; Nicolas 2009; ; Fortanier and Tulder 2009; Nicolas and Thomsen 2008; Amighini et al. 2008; Yeung and Liu 2008; UNCTAD 2006; Deng 2004, 2007; Schuller and Turner 2005;). Note that push and pull factors critically depend on the type of the investing firms and, in turns, they design the geography of outward direct investments. Evidence shows that state-owned enterprises, enjoying strong government support, mainly expand overseas to access natural resources, and they target developing countries. On the contrary, private firms respond to market stimulus, such as competitive pressure, over-capacity or availability of capital, and they invest abroad to appropriate strategic resources; for this reason, they target industrialized hosts, the most (Filippov and Saebi 2008).

As far as the entry mode decision is concerned, Dragon multinationals operate abroad via Joint Venture (JV), Merger \& Acquisition (M\&A) or Greenfield FDI, carried on in Wholly-Owned Subsidiaries (WOSs). Depending on whether the investor is rich or poor in intangible resources, and whether the host market is developed or developing, one entry mode is more likely to prevail over the others. As mentioned in Amighini at al. (2008, 2009), past operations were usually carried

\footnotetext{
${ }^{7}$ As pointed out in Haase et al. (2008), Chinese producers experience over-capacity in a number of sectors, such as refrigerators (40\%), microwave ovens (45\%) and televisions (87\%).
} 
on via Greenfield or JV and they were directed towards emerging economies; recent operations are mainly based on M\&A and they concentrate in industrialized countries. Put another way, M\&A and JV provide a privileged gate to foreign strategic assets, while Greenfield WOS represent the natural way preserve own resources (Nicolas 2009; Nicolas and Thomsen 2008; Deng 2007; Child and Rodrigues 2005; Schuller and Turner 2005). Entry mode decisions have been investigated econometrically by (Cui et al. 2008; Filatochev et al. 2007). Cui et al. (2008) analyse the choice of JV versus WOS in a sample of 138 Chinese MNEs. Their estimates show that the major differences between Chinese and Western multinationals regard organizational capability and strategic behaviour approach, while they exhibit the same attitude according to the institutional or transaction cost perspective. Filatochev et al. (2007) regress Taiwanese investment choice on a number of firm-level variables, to address the potential link between entry mode, corporate governance and location. They show that the choice of the equity stake in a local subsidiary depends on the share of family and institutional ownership in the parent company. Moreover, high commitment entry is associated with the affiliate being located in areas with strong economic, cultural and historical link with the parent company.

\section{Macroeconomic evidence about Chinese ODI}

The present Section offers an updated overview of recent trends characterising Chinese ODI. The benchmark picture presented here is then dissected in Section 4. Chinese outward direct investments have evolved in size, sector and geographical distribution over time. By the end of 2007, nearly 7,000 Dragon firms have established more than 10,000 overseas subsidiaries, spreading in almost 200 countries worldwide (MOFCOM 2008). The accumulated outward FDI stock accounted for 95,799 million USD and outflows reached 22,469 million USD.

Figure 1: Chinese FDI outflows by destination country (non-financial), 2005-2007

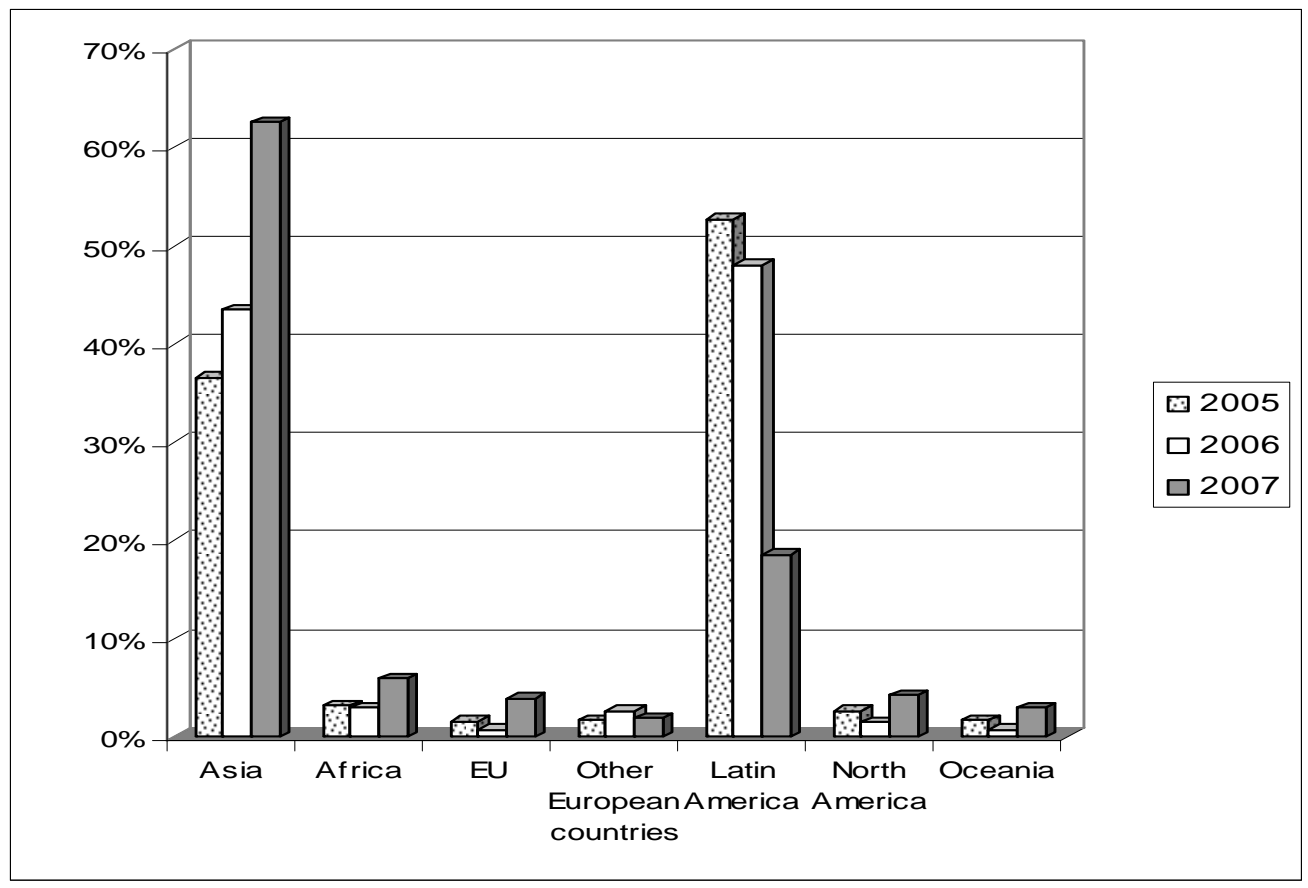

Source: personal elaborations from MOFCOM (2008) 
Figure 1 shows the geographical distribution of Chinese outflows by destination, in the period 2005-2007. Based on recent data, Asia is attracting the largest share of overseas operations, with increasing importance over the years 2005, 2006, 2007. Latin America can be regarded as a leading target as well, but its weight has decreased over time, while Africa, North America, Oceania and the EU accounted only for a limited percentage even if their role, as a recipient country, is larger today compared to the past ${ }^{8}$. Based on Figure 1, Chinese MNEs exhibit a strong investment concentration in a small number of destinations, especially high income developed countries. This is a striking difference, compared to other emerging economies that tend to target similar markets (Deng 2004, 2007). As far as the European Union is concerned, its percentage of total Chinese ODI in 2007 amounts to $4 \%$ reaching 1044 million USD, so the phenomenon is dynamic but still modest, as pointed out by Nicolas (2009). Moreover, this percentage is not equally distributed across the member states. Based on Table 1, the UK is the largest recipient, accounting for 32\% of the overall stock, followed by Germany (30\%), Spain (6\%), Poland (4\%) and Italy (3\%). As mentioned before (see Section 2), there exists a close relationship between the sector and geographical distribution of outward direct investments. Africa and Latin America tend to be targeted for abundance of natural resources, whereas Europe and North America are primarily accessed because of market- and asset-seeking considerations. While the early protagonists of Chinese internationalization were state-owned enterprises, operating in a highly regulated policy environment and motivated by the hunt for natural resources, new actors are now appearing in the international arena, driven by global ambitions and strategic considerations. Although some investments are still intended to secure raw materials and they involve state-owned enterprises, the large majority of the projects are now driven by international and domestic competition. Put another way, Chinese firms are encouraged to go abroad to acquire those skills and technologies that inward flows were not able to deliver. This is particular evident in the EU, where localization is dictated by purely opportunistic considerations. In fact, Chinese investors tend to select the sectors for which a given country has a particular strength; therefore, they invest in machinery in Germany, in automobile in the UK and in design in Italy, to capture externalities created by host country intangible asset clusters (UNCTAD 2004).

Table 1: Chinese ODI in Europe, by host country, 2005-2007 (mln USD)

\begin{tabular}{|l|r|r|r|r|r|}
\hline & flows 2005 & flows $\mathbf{2 0 0 6}$ & flows 2007 & stocks 2007 & \% on Europe \\
\hline UK & 24.78 & 35.12 & 566.54 & 768.41 & $32 \%$ \\
\hline Germany & 128.74 & 76.72 & 238.66 & 710.69 & $30 \%$ \\
\hline Spain & 1.47 & 7.3 & 6.09 & 142.81 & $6 \%$ \\
\hline Poland & 0.13 & 4.75 & 11.75 & 98.93 & $4 \%$ \\
\hline Italy & $\mathbf{7 . 4 6}$ & $\mathbf{7 . 6 3}$ & $\mathbf{8 . 1}$ & $\mathbf{8 2 . 5 1}$ & $\mathbf{3 \%}$ \\
\hline Romania & 2.87 & 9.63 & 6.8 & 72.43 & $3 \%$ \\
\hline France & 6.09 & 5.6 & 9.62 & 54.5 & $2 \%$ \\
\hline Europe & 189.54 & 128.73 & 1045.07 & 2385.13 & $100 \%$ \\
\hline \multicolumn{7}{|c|}{ Source: personal elaborations from MOFCOM (2008) }
\end{tabular}

\footnotetext{
${ }^{8}$ Similar results hold when we look at the accumulated FDI stock.
} 
Figure 2 displays the composition of Chinese ODI in 2007, by economic activity. Based on these data, wholesale and retail sale account for the largest percentage of overseas operations 25\%), followed by leasing and business services (21\%), mining (15\%), transport (15\%) and manufacturing (8\%). This is not surprising, since China has still a comparative advantage in terms of production efficiency, due to cheap inputs and low labour costs, therefore manufacturing activities tend to be performed domestically rather than off-shored.

Before concluding this Section, it is worth mentioning that China is as large as continent, which makes it challenging to explore its global involvement at the provincial level, to see whether internationalization is a widespread phenomenon or it involves a limited number of regions. Based on MOFCOM (2008), within mainland China, Guangdong is the most important home for FDI outflows in 2007 (18\%), followed by Shenzen (15\%), Shanghai (8\%), Jiangsu (8\%) and Zheijiang (6\%). Actually, foreign direct investment is not equally promoted throughout the country, but it looks rather clustered across a few coastal regions that are also the main recipient of FDI inflows.

Figure 2: Chinese FDI outflows by economic activity (non-financial), 2007

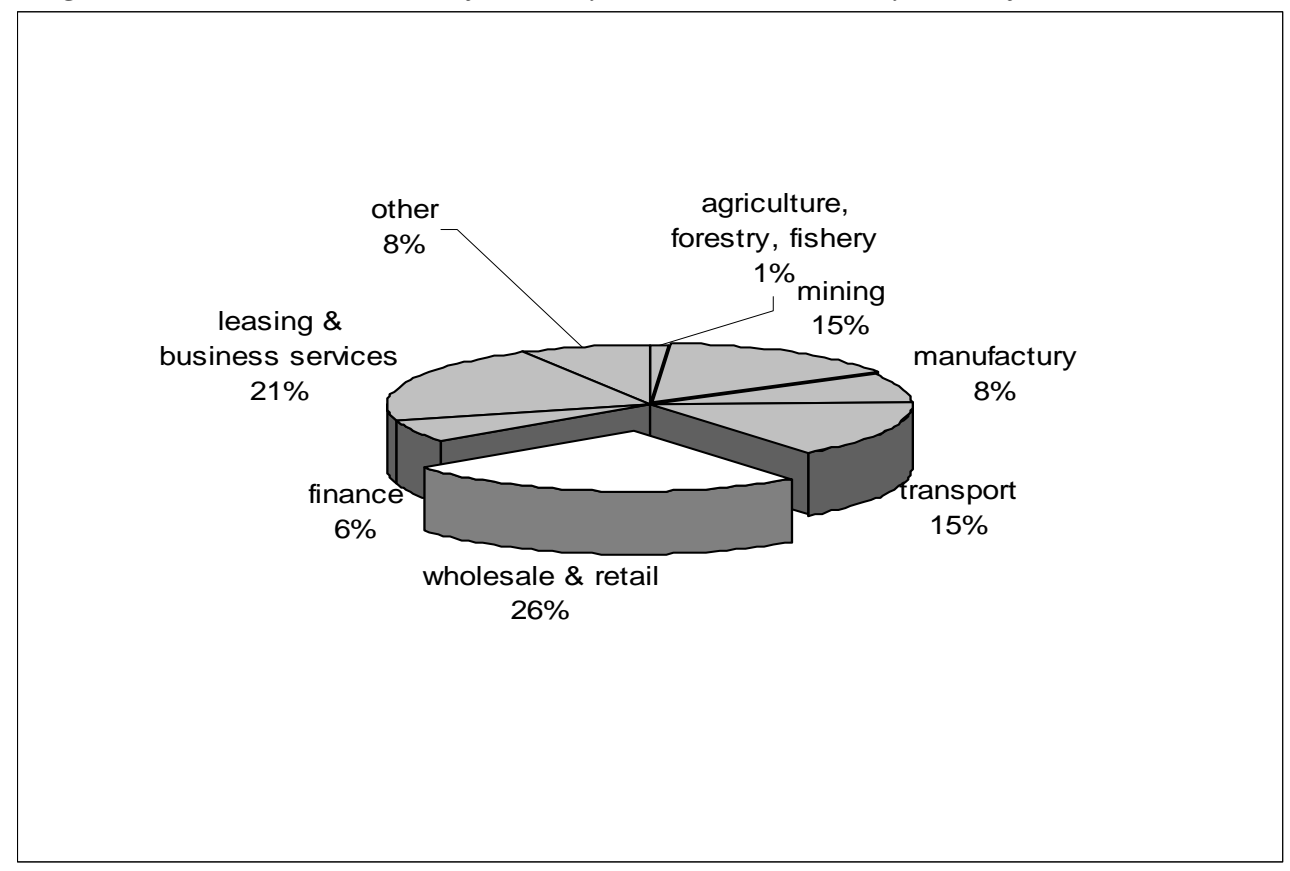

Source: personal elaborations from MOFCOM (2008)

\section{Microeconomic evidence about Chinese ODI}

After describing recent trends in Chinese internationalization paths, this Section dissects the macro evidence reported above, by means of firm-level data. If China's global involvement has strengthened over time, what are the drivers of outward direct investments? What lays behind their sector and geographical distribution? Why some countries are targeted more than others? Is it dependant on returns and problems encountered in the local economy?

To answer these and similar questions, we select Italy, among the main recipient countries, and provide original evidence about Dragon MNEs there. Our data 
derive from a comprehensive survey, conducted in 2009: (4.1) reviews the empirical methodology, (4.2) draws a portrait of Chinese parent companies and (4.3) summarizes the main features of their FDI.

\subsection{Methodology}

The present research builds on a multiple-choice questionnaire about Dragon MNEs, designed by the author, according to the existing literature (see Section 2). The questionnaire is made of two sections. First, we ask background information about the parent company, ranging from balance sheet data to human capital details and international experience. Second, we investigate the strategic drivers behind Chinese ODI, such as push and pull factors, location and entry mode decisions, returns and problems related to direct investments, for around 50 questions overall. Building on this questionnaire, detailed interviews have been conducted with senior managers of Chinese affiliates in Italy, between April and September 2009. In order to provide a comprehensive census of Dragon MNEs, we targeted the entire population of firms, rather than restricting attention to a given industry or region. The original list of investors was compiled through a number of sources, such as the database ICE-Reprint, Amighini et al. (2008) and Spigarelli (2009), for a total number of 31 Chinese ODIs. We then submitted the questionnaire both electronically (40\%) and by phone (60\%).

With an exceptional reply rate of $65 \%$, the present paper documents 20 direct investments disseminated throughout 49 operating plants in the Italian market. To the best of our knowledge, this is the first attempt at collecting survey data about Chinese ODI at the micro level, offering such a deep picture, both in terms of sample representativeness and topic coverage.

In what follows, the main survey results are commented; particular attention is devoted to the matching between empirical findings and theoretical expectations.

\subsection{Portrait of Chinese parent companies}

A preliminary look at the survey responses suggests that the profile of Dragon MNEs in Italy is very diverse.

As far as the number of employees is concerned, Figure 3 shows that Chinese parent companies are rather large: based on our data, most firms (58\%) have more than 15,000 employees, and some of them (8\%) top 100,000 employees. This is an interesting feature, especially when looking at the Italian market, which is characterized by a massive presence of small and medium enterprises. 
Figure 3: Number of employees of Chinese parent companies

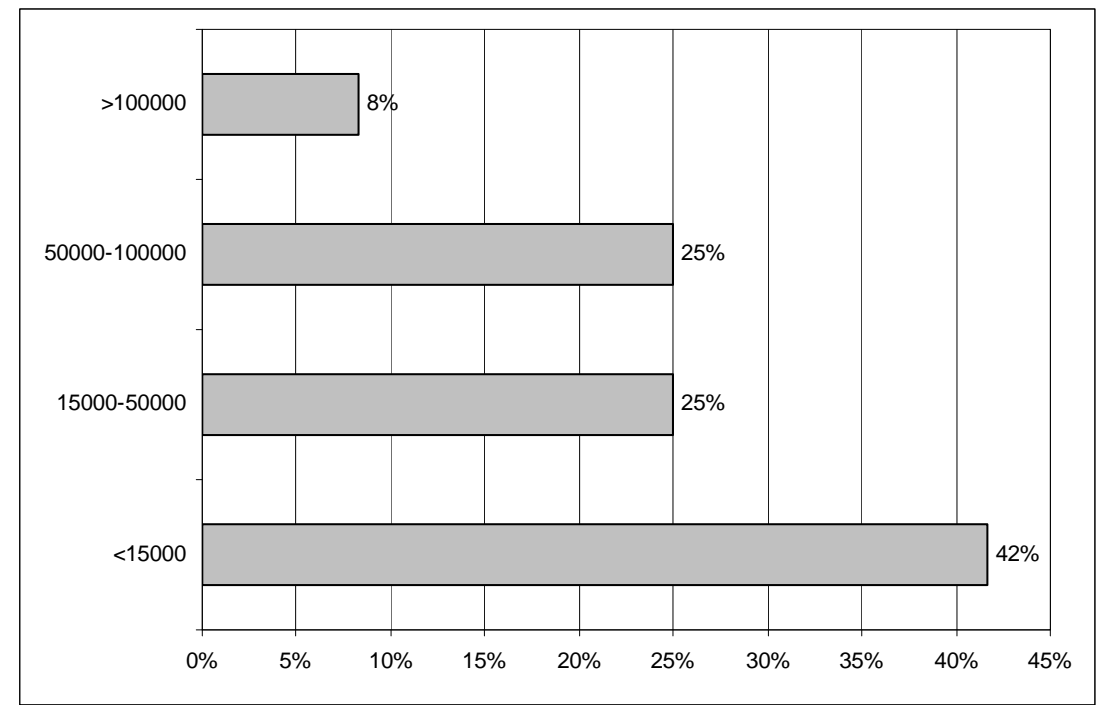

Similar results emerge if we analyze total sales: interviews reveal that $67 \%$ of Chinese parent companies have sales larger than 1 billion Euro, and 25\% of them exceed 10 billion Euro as an yearly turnover. These data are in line with the portrait of main investors coming from emerging economies, drawn in (UNCTAD 2006; Amighini et al. 2009), where the presence of large corporations with global ambitions is documented.

To go deeper into the characteristics of investing firms in Italy, Figure 4 displays their sector composition. Consistently with (Buckley et al. 2008a; UNCTAD 2006), they belong to industries such as automotives (8\%), electronics (25\%), home appliances (17\%), transport (33\%) and telecommunication (17\%), the most.

Figure 4: Industry of Chinese parent companies

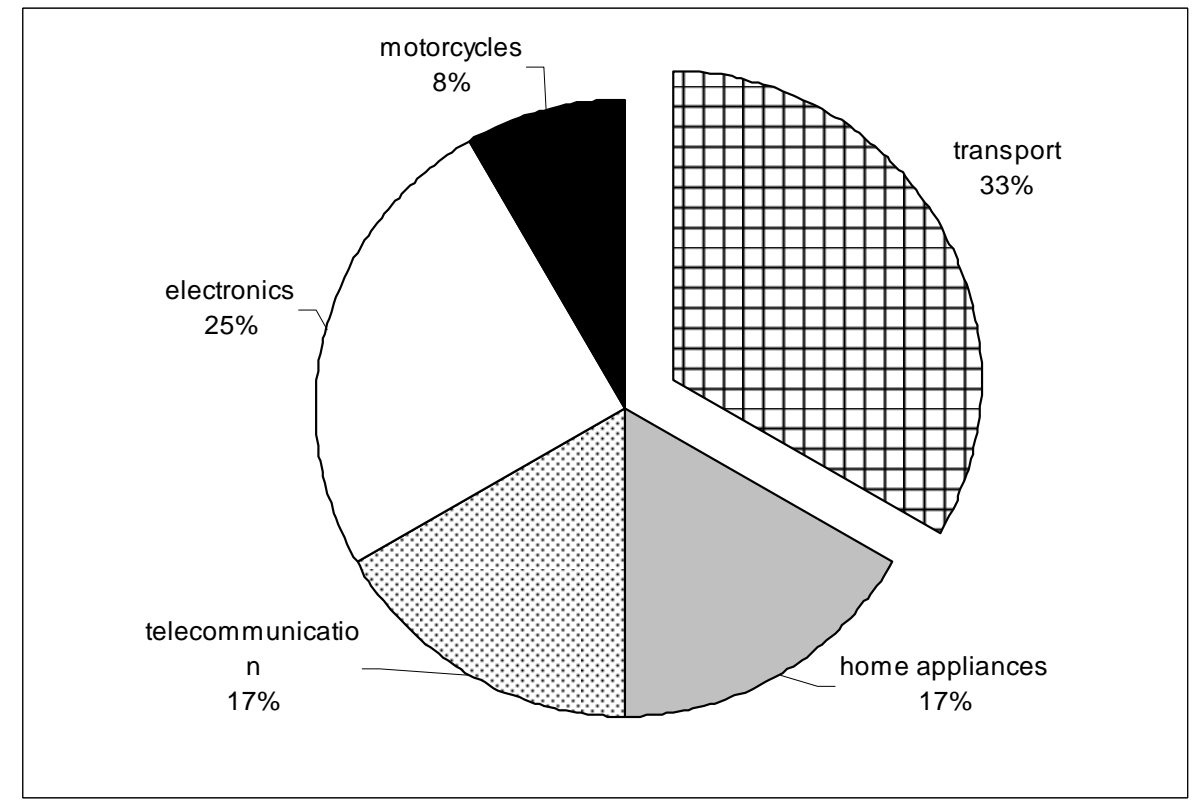


As for the province of origin, Figure 5 shows that Hong Kong is the main source of outflows, amounting to $25 \%$ of the total, followed by Beijing, Taiwan and Zhejiang, accounting for $17 \%$ each, and Shanghai (8\%), Shenzen (8\%) and Shandong (8\%). This geographical distribution is not surprising in light of the historical pattern of Chinese internationalization and growth. As mentioned before (see Sections 1 and 3), under the "Open Door" policy, the country experienced fast development and structural changes, starting from a few economic zones, located along the coastal region, and moving only lately to inner areas. Hence, today's China is characterised by a sharp dualism, with a narrow modern and relatively rich east, along the coast, and a wide developing and poor west ${ }^{9}$. Not surprisingly, the geography of FDI shows a marked concentration in more developed areas, where inflows are directed and outflows originate.

The questionnaire then explores the international experience of Dragon MNEs. According to our survey, only $40 \%$ of the respondents had some contact with Italian enterprises before the current FDI. However, if we broaden our perspective, zooming on Europe, rather than Italy, we discover that two thirds had various kinds of international business in the past, from import/export (33\%) to FDI (17\%), from representative offices (17\%) to licensing agreements (8\%). Similarly to Buckley et al. (2008a), these data show that, overall, Dragon MNEs have accumulated a good deal of experience in running foreign operations before the current involvement.

Figure 5: Province of origin of Chinese parent companies in Italy

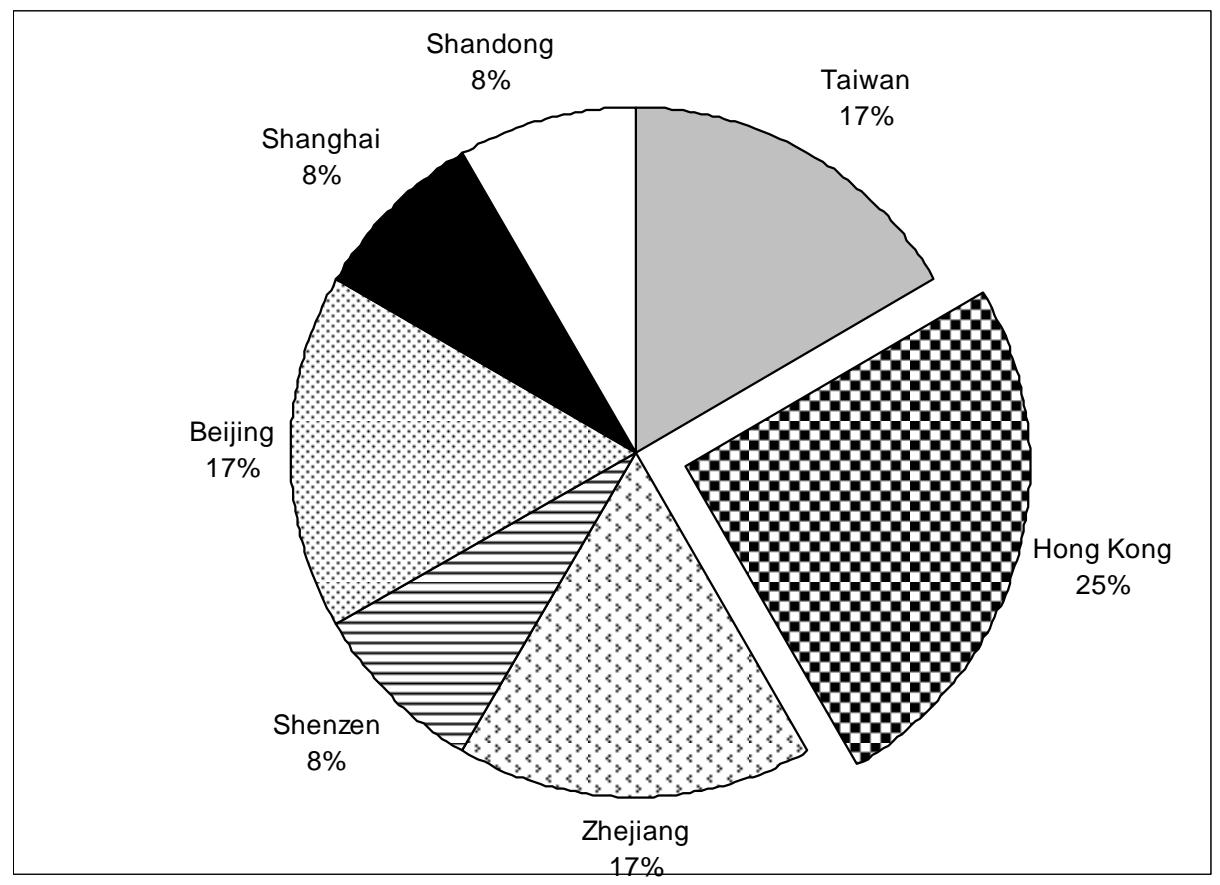

\footnotetext{
${ }^{9}$ More details about the “Open Door” policy can be found in (Berger and Berkofsky 2009; Buckley et al. 2008b; Poncet 2007; Zhang Y. 2005).
} 
On the contrary, human capital proxies perform poorly since the percentage of employees holding a degree is, on average, $40 \%$, and investiments in $\mathrm{R} \& \mathrm{D}$ are usually below $10 \%$ of total sales.

To complete our portrait of Dragon multinationals in Italy, Figure 6 displays their composition by type of firm. Following Deng (2007), we distinguish among stateowned enterprises (SOEs), collective, private, and mixed firms ${ }^{10}$. Consistently with (Amighini et al. 2009; Yeung and Liu 2008; UNCTAD 2006), empirical evidence reveals that the majority (34\%) of Chinese parent companies is state-owned, closely followed by the group of private (33\%), mixed (25\%) and collective (8\%) firms.

Figure 6: Type of firm of Chinese parent companies in Italy

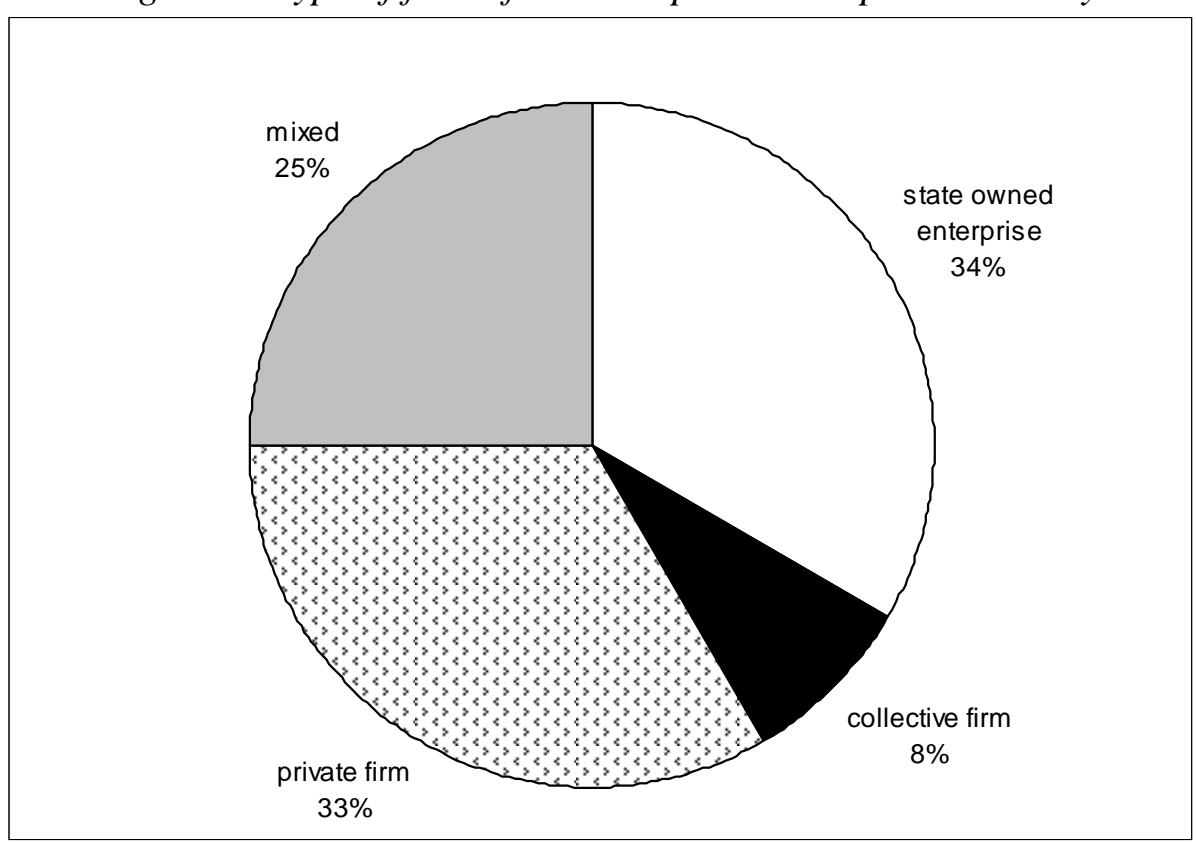

\subsection{Characteristics of Chinese ODI in Italy}

Having sketched the portrait of Chinese enterprises in Italy, we now characterize the main features of their direct investment.

Notice that the type of firm, summarized in Figure 6, is a crucial information when dealing with push and pull factors, because the attractiveness of a given market may depend, other things being equal, on the characteristics of the investor. According to the related literature (see Section 2), Figure 7 identifies three potential push factors: government support, the presence of capital to invest and the stagnancy of the domestic market. Empirical evidence suggests that government support is a key push for state-owned and collective firms, while the presence of capital to invest is particularly relevant for private and mixed enterprises, and the stagnant domestic market encourages the internationalization of private companies and SOEs.

A similar analysis is conducted in terms of pull factors. Based on Dunning (1993), they are usually grouped into the three categories of market-, resource- and

\footnotetext{
${ }^{10}$ For more details about the Chinese industrial transformation, and the various types of firms, see (Wang and Szirmai 2008; Amighini and Chiarlone 2007; Chan 1995).
} 
efficiency-seeking considerations. Our questionnaire adopts a rather richer classification, as shown in Figure 8. Broadly speaking, the possibility to exploit Italy as a strategic platform to Europe, the presence of local distribution networks and the business potential belong to the first category; the availability of established brands and advanced technology, together with the abundance of high skilled labour force and specialized suppliers belong to the second; while efficiency considerations, in the Italian case, seem to be confined to the possibility to avoid trade barriers. Since there is no striking difference by type of parent company, Figure 8 reviews the main pull factors from the aggregate sample. As pointed out in (Athreye and Kapur 2009; Fortanier and Tulder 2009; Nicolas 2009; Amighini et al. 2008; UNCTAD 2006; Schuller and Turner 2005; Zhang 2005; Yeung and Liu 2008; Wu 2005; Deng 2004), market-seeking FDIs are predominant for Dragon MNEs. Indeed, based on our data, the possibility to find a strategic platform to Europe (30\%) and the business potential (23\%) rank first and second among pull factors. Resource-seeking FDI, especially in the form of strategic asset-seeking operations are important as well, since Chinese MNEs target Italy due to advanced technology (13\%), established brands (10\%) and the presence of specialized suppliers (7\%), in line with the arguments of (Athreye and Kapur 2009; Duysters et al. 2009; Kumar and Chadha 2009; Nicolas 2009; Nicolas and Thomsen 2008; Amighini et al. 2008; Schuller and Turner 2005; Zhang 2005; Wu 2005; Deng 2004, 2007). On the contrary, efficiency-seeking considerations do not turn out as relevant drivers.

Figure 7: Push factors of Chinese parent companies in Italy, by type of firm

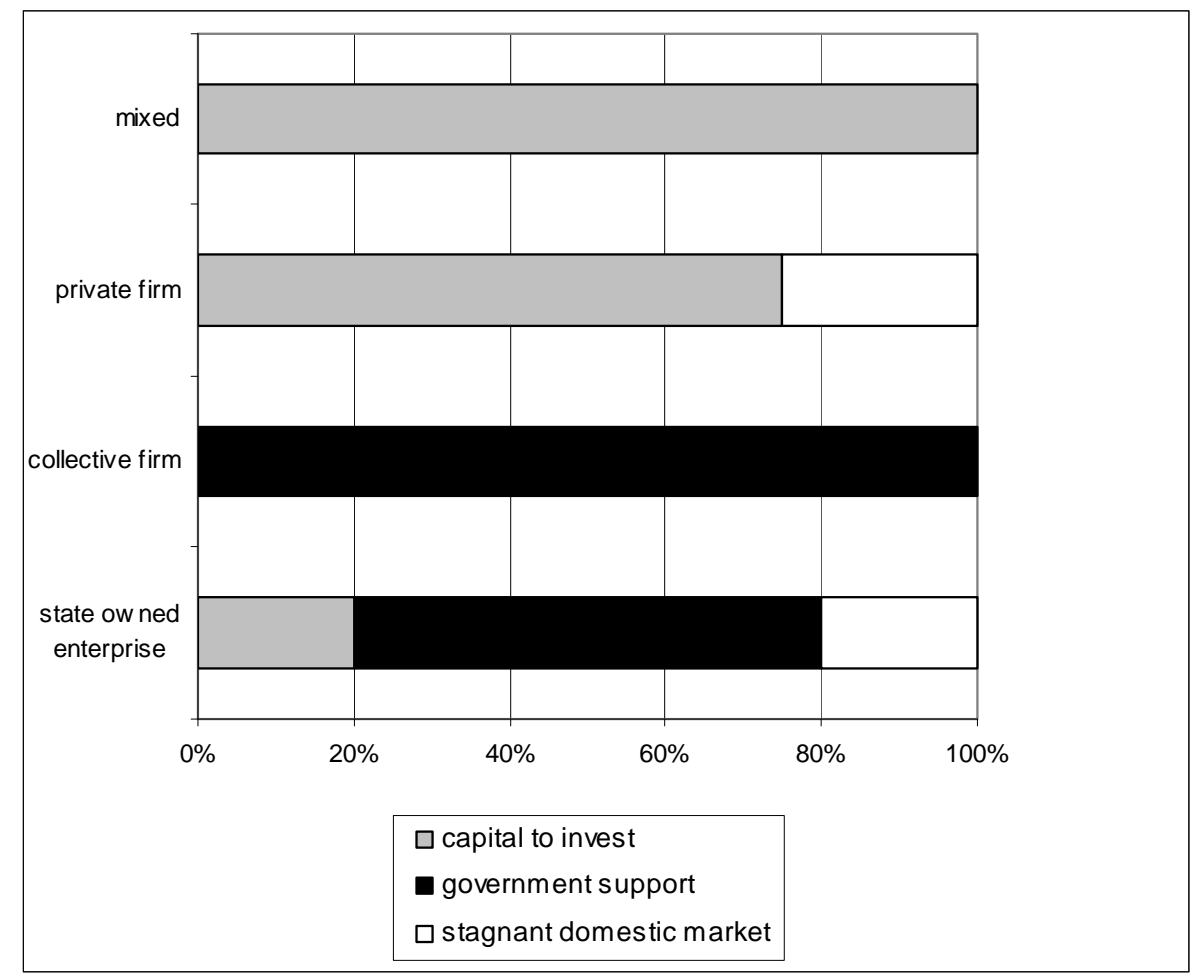

Despite the large size of Dragon multinationals (see Section 4.2), it is worth mentioning that the average amount of money invested in Italy is rather small. 
Only 33\% of the respondents spent more than 5 million Euro to establish local plants, while half of the sample spent less than 1 million ${ }^{11}$.

As far as the entry mode decision is concerned, Figure 9 disaggregates Chinese ODI by Merger \& Acquisition, Joint Venture and Greenfield WOS. Consistently with the existing literature (see Section 2), our data suggest that M\&A represents the main gate into the Italian market, preferred by $50 \%$ of the respondents; Joint Venture and WOE follow, accounting for $40 \%$ and $10 \%$, respectively. At this stage, note that entry mode strategies are highly correlated with the type of the parent company: while JVs are chosen only by state-owned and collective enterprises, private and mixed companies tend to select Merger \& Acquisition strategies when expanding abroad. Some authors (see, among others, Deng 2007) suggest out that entry mode decisions have evolved over time, shifting resources from Greenfield to M\&A, so that acquisitions are nowadays the predominant mode to access foreign markets. This might be a possible explanation for the massive presence of Chinese M\&A in Italy, although the cross sectional nature of our data do not allow for a dynamic perspective. Another potential argument, due to Amighini et al. (2009), is that Mergers \& Acquisitions usually provide access to technology, human capital and brand, hence they are a typical channel to developed host economies, whereas Greenfield operations, aimed at consolidating and exploiting already existing assets, tend to prevail in developing countries. Along this argument, Joint Venture represents an intermediate entry mode, particularly useful to extract natural resources. Given that Italy is an advanced economy, but poor in raw materials, not surprisingly M\&A represents the main gate to the country.

Figure 8: Pull factors of Chinese parent companies in Italy

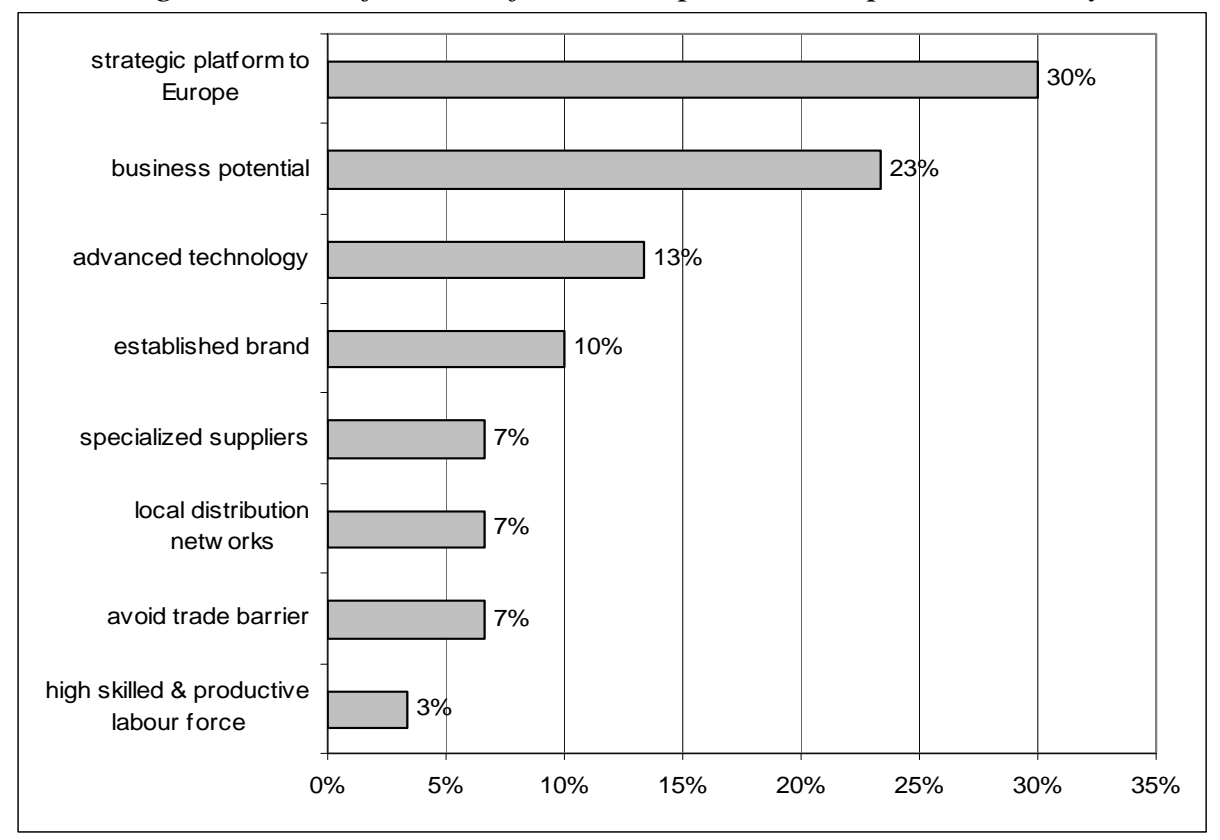

11 Investments are usually larger, when Greenfield wholly-owned enterprises are set or full acquisitions are contracted, as opposed to Joint Venture establishments. 
Based on Figure 10, Dragon multinationals tend to acquire Italian enterprises to smooth potential conflict with the local affiliate (38\%), to diversify their products and exploit local networks (24\%), and to cut production (23\%) or marketing costs (23\%). Notice also that full acquisitions account for the large majority (80\%) of the M\&A operations. Following closely Nicolas and Thomsen (2008), our data confirm that Chinese firms usually acquire three main categories of enterprises: ailing or financially distressed firms (20\%), competitive niche producers (40\%) and former partners/subcontractors/suppliers (30\%). Only a small percentage of M\&A (10\%) instead involves Italian companies characterized by a wide distribution network, along the argument of Schuller and Turner (2005). In fact, Dragon MNEs tend to contribute financial strength, but they lack technical expertise and established reputation; at the same time, many European firms, even if endowed with know-how and brand name, experience serious financial difficulties. Hence, a perfect matching results when they decide to merge.

Figure 9: Entry mode choice of Chinese parent companies in Italy

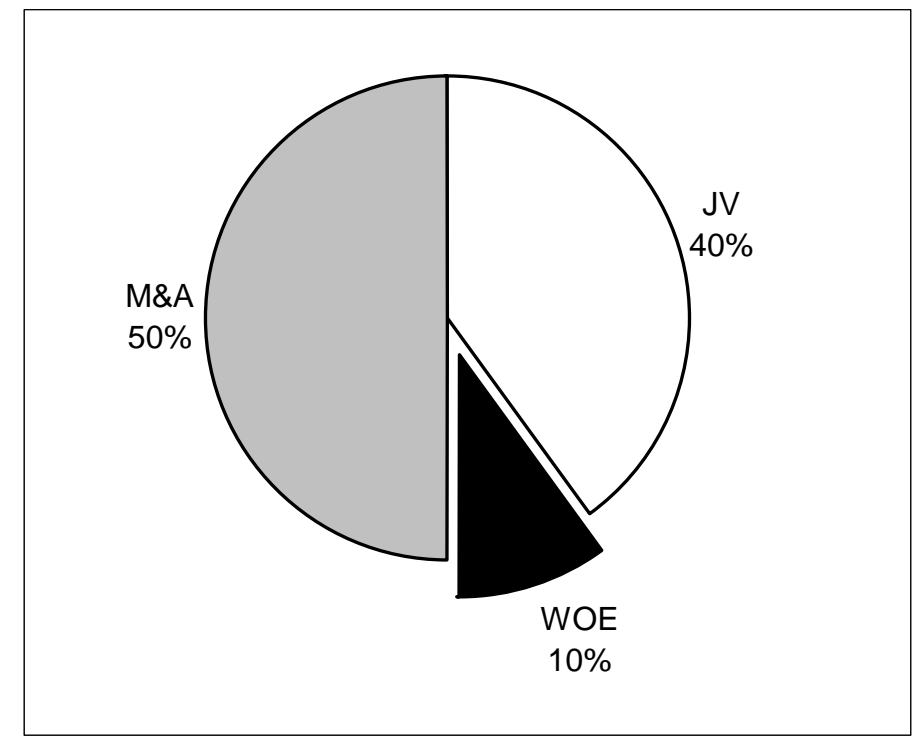

As far as the Joint Venture is concerned, Figure 11 summarizes the main reasons to look for an Italian partner. Consistently with Child and Rodrigues (2005), Joint Ventures offer the opportunity to gain local support (40\%), to build reputation (20\%), to learn international technology and know-how (20\%), and to share risks and costs (20\%). If we further analyse the specific contribution of each partner, we find that the Italian company usually provides technology, while the Chinese enterprise contributes capital.

At this stage it is worth mentioning that different criteria are followed to select the local counterpart. Based on our data, strategic and organizational motivations rank first, accounting for 39\% each of the total, followed by geographical (17\%) and fortuitous (6\%). This means that Chinese investors care about the partner's experience, human capital and network the most, but they also consider his/her location within the Italian market, as a key for a successful partnership. 
Figure 10: Reasons to enter the Italian market through M\&A

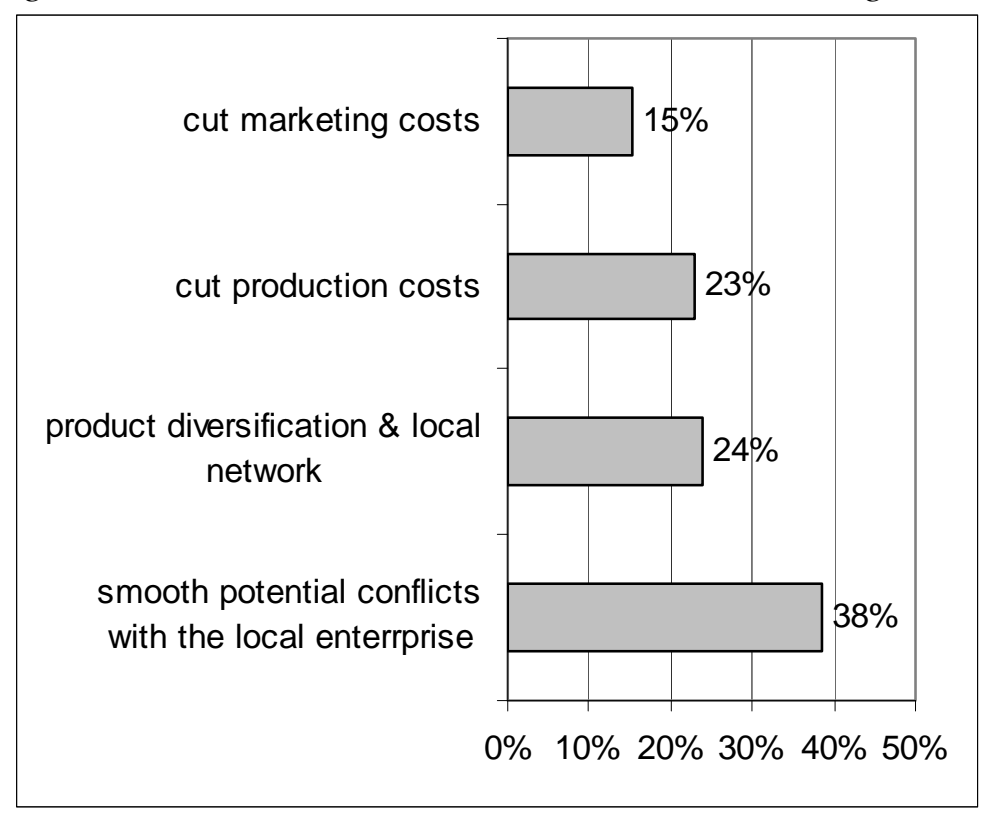

After analysing M\&A and JV, to complete the picture about entry mode strategies, Figure 12 reveals the main reasons to opt for a WOE, according to the respondents' answers.

Figure 11: Reasons to enter the Italian market through JV

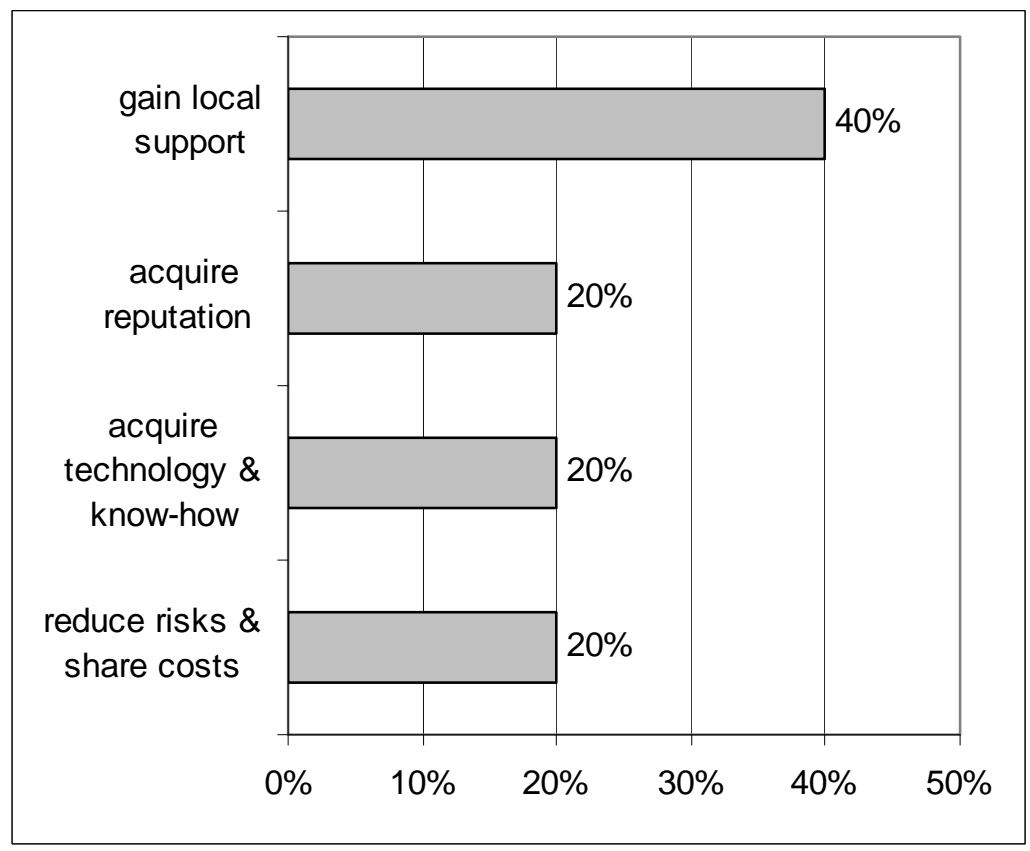

As mentioned in Section 2, Greenfield establishments in developed countries are usually aimed at facilitating access to the local market, and customising final products for local consumers. This kind of operations is typical of some sectors such as transport and telecommunication - and some investors - namely those endowed with competitive advantages at home, and seeking to strengthen their 
market share abroad. While M\&A and JV represent a privileged way to acquire strategic assets, wholly-owned enterprises are set in order to preserve intangible resources (50\%) or to strengthen own brand's credibility (50\%), consistently with (Nicolas 2009; Deng 2007).

Based on Figure 13, the overall level of satisfaction about Italian operations is extremely high. Indeed, all Chinese firms running WOE or M\&A are very satisfied, while the evidence about JV is mixed, with $35 \%$ of the respondents very satisfied, 50\% not satisfied and wishing to switch to WOE, and 25\% planning to disinvest.

Figure 12: Reasons to enter the Italian market through WOE

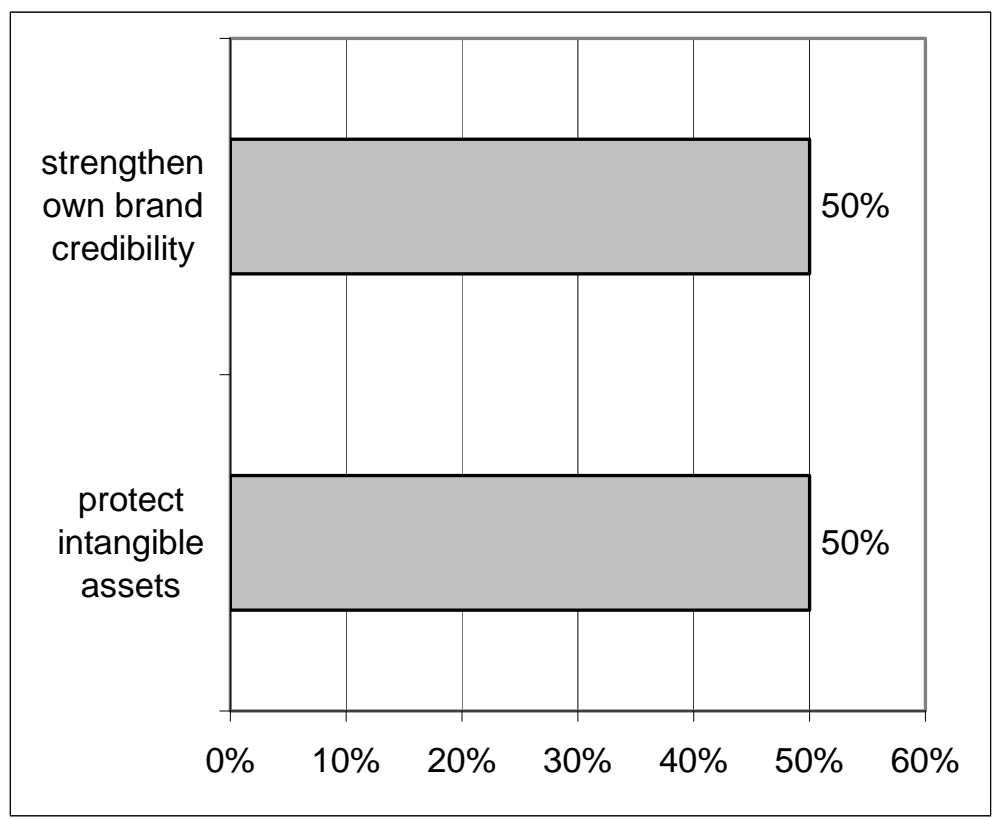

Figure 13: Satisfaction about Italian operations, by entry mode

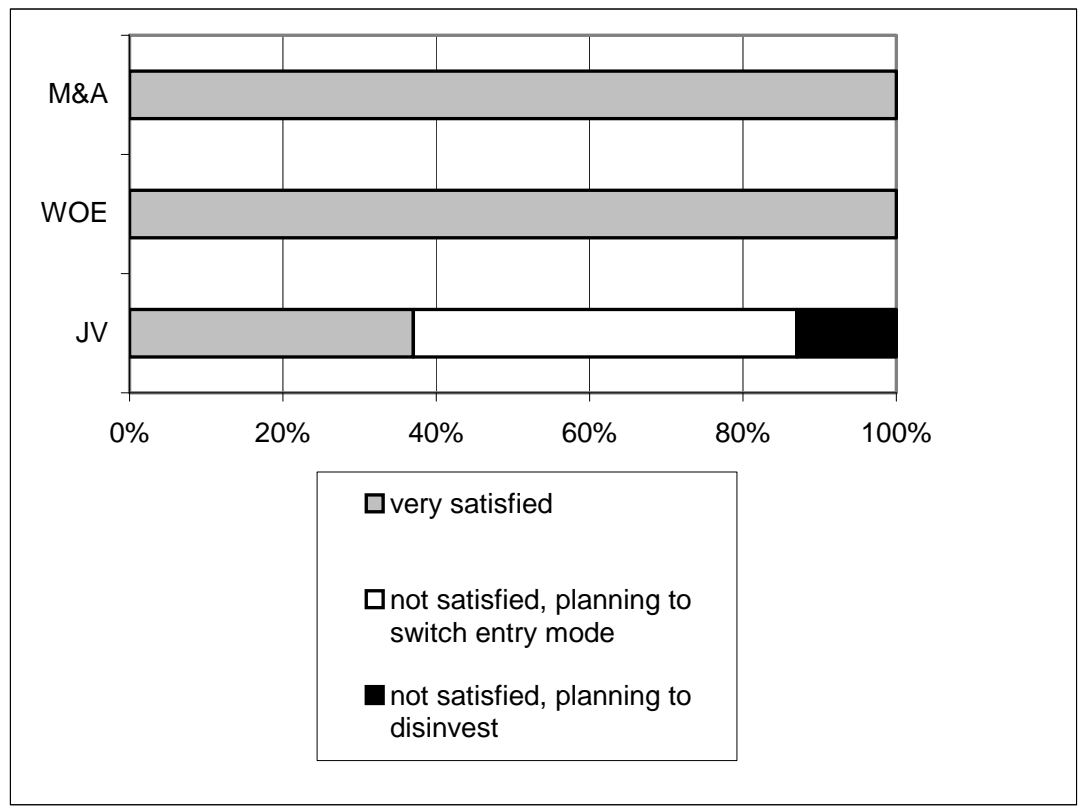


According to our survey, the main returns from direct investments in Italy range from access to new market segment (30\%) to improved image and reputation (21\%), from increased sales or better competitive position (16\%) to updated technology (14\%) and lower input costs (2\%) (see Figure 14).

Despite this long list of returns, many problems still plague the experience of Dragon MNEs, from cultural distance (24\%) to the lack of labour market flexibility (20\%), from bureaucracy (20\%) to unfavourable living conditions (12\%), from the language (10\%) to the lack of infrastructures (2\%). To sum up, according to Figure 15 , only $12 \%$ of Chinese parent companies do not face any serious problem in Italy, while the vast majority is struggling against a system that is very different from the one prevailing in the home country. As a result, future plans consist of keeping the current investment for around $70 \%$ of the sample, expand the Italian operations by means of new plants or additional money for $19 \%$ and $5 \%$, and leave the host country for $5 \%$ of respondents.

Figure 14: Main returns from Italian operations

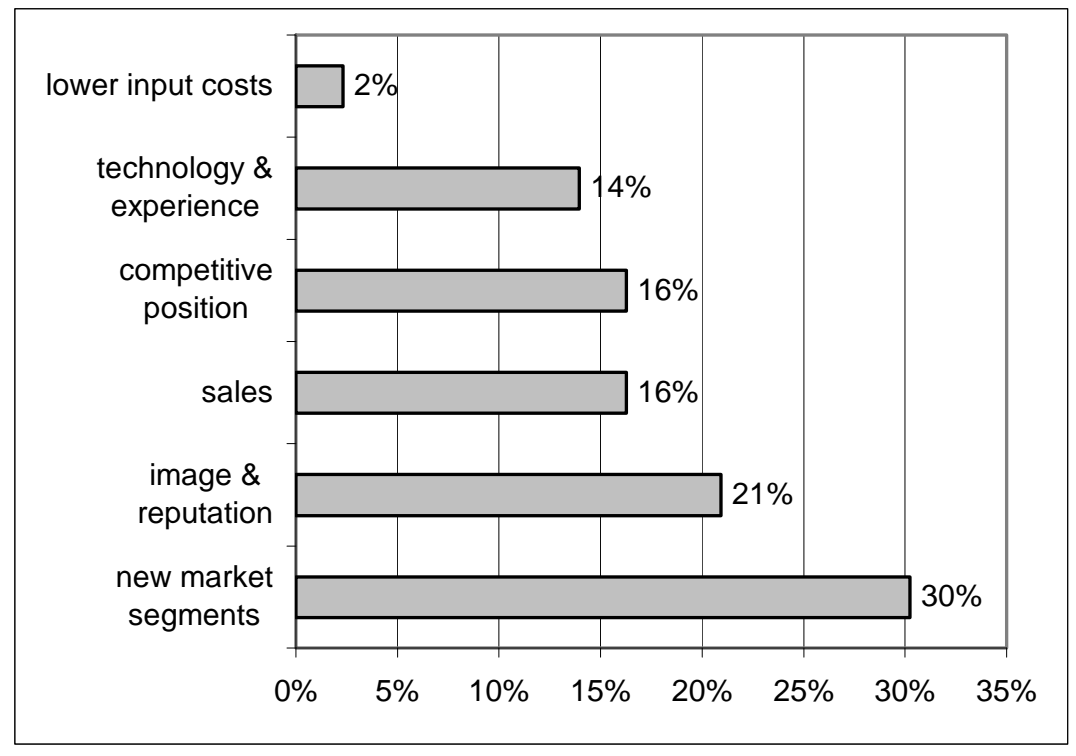

Figure 15: Main problems encountered in Italy

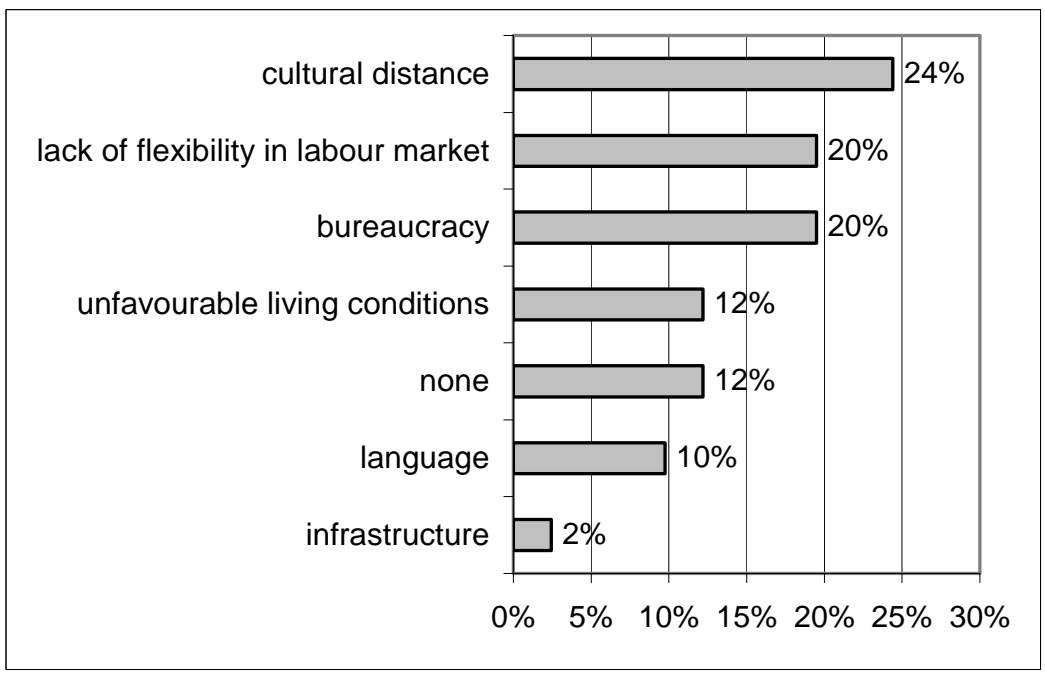




\section{Conclusion}

The popularity of inward FDI to China, over the past three decades, has been recently mirrored by its outward flows, greeted with a mixture of enthusiasm and concern all around the world. As Zhang Y. (2005) points it out, China's engagement with the global market is unprecedented, both in terms of intensity and breadth. If the Chinese threat for Europe and Italy has been modest so far, due to the limited number of operations (Nicolas 2009), the rise of the Dragon is fast and dynamic, so as to deserve attention from market players, policy makers and researchers.

While most studies about Chinese ODI are qualitative, this paper provides original evidence of Dragon multinationals in Italy, at the micro level. Data have been collected through a multiple-choice questionnaire, designed by the author and submitted to the entire group of Chinese parent companies. With a reply rate of $65 \%$, we present an exhausted survey of 20 FDIs, corresponding to 49 operating plants. Empirical findings are strongly consistent with the theoretical expectations reviewed in Section 2. Indeed, Chinese investors are rather large companies, characterized by a high degree of state ownership. They come from Hong Kong, Taiwan and the modern East of mainland China, and they belong to industries such as transport, electronics, telecommunications and home appliances. Evidence also shows that Dragon MNEs target Italy motivated by market- and resource-seeking considerations, as a pull factor, together with government support and the availability of capital, as a push force. The level of satisfaction with the local operations is generally high, and the main returns from FDI range from access to new market segments to improvements in image and reputation, from increased sales and competitive position to better technology. Chinese enterprises further reveal a strong preference towards Mergers \& Acquisitions, followed by Joint Ventures, and they lament cultural distance, bureaucracy and the lack of flexibility in the Italian market.

We believe that this paper comprises a few novelties, compared to the existing literature. First, it provides a quantitative, rather than qualitative analysis of Chinese ODI, different from the greatest bulk of the contributions reviewed in Section 2. Second, within the small group of empirical studies, it takes a micro, rather than a macro perspective. This allows us to dissect the general trends, highlighted in Section 3, and read behind aggregated numbers, at least for Italy. Third, within to the tiny group of micro papers, it bases on original survey data, rather than case histories, sector or anecdotal studies. This provides a broader and more solid ground for the empirical analysis. Finally, compared to (Cui et al. 2008; Buckley et al. 2008a; Zhang 2005) that employ multiple-choice questionnaires to collect or complements information at the firm-level, we offer a richer framework in terms of sample representativeness, number of questions and variety of issues covered.

Nonetheless, a few limits are worth mentioning too. For example, despite the high reply rate, the small number of observations dos not allow for a proper econometric exercise. This is the reason why results in Section 4 are presented only in terms of summary statistics and graphs. Moreover, even though the main findings are consistent with the existing literature, they might be biased by the choice of the host country. Put another way, the focus on Italy, rather than other or 
more countries, prevents us from generalizing results too much: the only message that we derive from the present exercise is that Chinese ODI in Italy support the previous qualitative literature on the same topic.

To overcome the issue of data limitation, and capitalize on the promising results reported in Section 4, we believe that further evidence, at the micro level, should be collected, to better characterize emerging countries outflows. For instance, an extension of this survey to a broader array of host economies, would allow for a cross-country comparative analysis and a deeper dissection of the aggregated picture reported in Section 3. Moreover, an extension of the same survey, to embrace other emerging economies would complement our portrait of Chinese investors and better describe their attitudes towards internationalization.

On our opinion, both extensions are worth carrying on, because they would be extremely challenging from an academic and a policy perspective. On the one hand, more advanced statistical analysis could be performed and theoretical models could be rigorously tested. On the other hand, given that the Dragon has begun to rise, it is important to have a clear comprehension of this phenomenon. How Chinese firms adjust to and learn from the global marketplace will not only affect China's economic future, but also China's relation with the rest of the world. 


\section{References}

Amighini, A. and S. Chiarlone (2007), 'La trasformazione dell'economia cinese: proprietà dell'impresa e modello di specializzazione', Economia e Politica Industriale, 3, 185-200.

Amighini, A., R. Rabellotti and M. Sanfilippo (2009), 'The Rise of Multinationals from emergine Countries. A Review of the Literature, Emerging Economic Regional Powers and Local Systems of Production: New Threats or New Opportunities?', Working Paper Series, 4/09.

Amighini, A., R. Rabellotti and M. Sanfilippo (2008), 'L'avanzata degli IDE cinesi in Italia', in Rapporto ICE 2007-2008, Roma: Istituto per il Commercio Estero.

Athreye, S. and S. Kapur (2009), 'Introduction: The Internationalization of Chinese and Indian Firms - Trends, Motivations and Strategy', Industrial and Corporate Change, 18(2), 209-221.

Aulakh, P.S. (2007), 'Emerging Multinationals from Developing Economies: Motivations, Path and Performance', Journal of International Management, 13, 235-240.

Berger, B. and A. Berkofsky (2008), 'Chinese Outward Investments: Agencies, Motives and Decision-Making', CASCC Briefing Paper, 172.

Boisot, M. (2004), 'Notes on the Internationalization of Chinese Firms'. Mimeo, Open University of Catalonia, Barcelona, Spain.

Buckley, P.J., L.J. Clegg, A.R. Cross, X. Liu, H. Voss and P. Zheng (2007), 'The Determinants of Chinese Outward Foreign Direct Investment', Journal of International Business Studies, 38(4), 499-518.

Buckley, P.J., A.R. Cross and H. Voss (2008a), 'Chinese Direct Investment in the United Kingdom: An Assessment of Motivations and Competitiveness', paper presented at the conference Corporate Strategies in the New Asia, 1-2 Fabruary 2008, University of Bremen.

Buckley, P.J., A.R. Cross and H. Voss (2008b), 'Thirty Years of Chinese Outward Foreign Direct Investment', paper presented at the CEA (UK) Conference China's Three Decades of Economic Reform (1978-2008), 1-2 April 2008, University of Cambridge, UK.

Cai, K.G. (1999), 'Outward Foreign Direct Investment: A Novel Dimension of China's Integration into the Regional and Global Economy', China Quarterly, 160, 856-880.

Chan, A. (1995), 'Chinese Enterprise Reform: Convergence with the Japanese Model?', Industrial and Corporate Change, 4, 449-470.

Child, J. and B. Rodrigues (2005), 'The Internationalization of Chinese Firms: A Case for Theoretical Extension?', Management and Organization Review, 1(3), 381-410.

Cui, L., F. Jiang and B.W. Stening (2008), 'Determinants of FDI Entry Mode Decisions of Chinese MNCs', paper presented at the AIBAIB Annual Meeting, 30 June-3 July 2008, Milan, Italy.

Deng, P. (2007), 'Investing for Strategic Resources and its Rationale: The Case of Outward FDI from Chinese Companies’, Business Horizons, 50, 71-81.

Deng, P. (2004), 'Outward investment by Chinese MNCs: Motivations and Implications’, Business Horizons, 47 (3), 8-16. 
Dunning, J.H. (1981), 'Explaining the International Direct Investment Position of Countries: Towards a Dynamic or Developmental Approach', Weltwirtschaftliches Archiv, 117(1), 30-64.

Dunning, J.H. (1993), Multinational Enterprises and the Global Economy. Addison Wesley:Mass.

Duysters, G., J. Jacob, C. Lemmens and Y. Jintian (2009), 'Internationalization and Technological Catching Up of Emerging Multinationals: a Comparative case Study of China's Haier Group', Industrial and Corporate Change, 18(2), 325-349.

Filatochev, I., R. Strange, J. Piesse and Y.C. Lieu (2007), 'FDI by Firms from Newly Industralized Economies in Emerging Markets : Corporate Governance, Entry Mode and Location”, Journal of International Business Studies, 38(4), 556-572.

Filippov, S. and T. Saebi (2008), 'Europeanisation Strategy of Chinese Companies: Its Perils and Promises', UNU-MERIT Working Paper Series, 55.

Fortainer, F. and R. van Tulder (2009), 'Internationalization Trajectories - a CrossCountry Comparison: Are Large Chinese and Indian Companies Different?', Industrial and Corporate Change, 18(2), 223-247.

Gao, L. (2008). 'Determinants of China's Outward Foreign Direct Investment', paper presented at the CEA (UK) Conference China's Three Decades of Economic Reform (1978-2008), 1-2 April 2008, University of Cambridge, UK.

Haase, E., M. Miglans and J. Nabradi (2008), 'Chinese Outbound FDI: Current and Future Role Based on the Example of Hungary, Latvia and Poland', CEMS, mimeo.

Kumar, N. and A. Chadha (2009), 'India's Outward Foreign Direct Investments in Steel Industry in a Chinese Comparative Perspective', Industrial and Corporate Change, 18(2), 249-267.

Li, P.P. (2007), 'Toward an Integrated Theory of Multinational Evolution: The Evidence of Chinese Multinational Enterprises as Latecomers', Journal of International Management, 13, 296-318.

Liu, C. Z. (2007), 'Lenovo: an example of globalization of Chinese enterprises', Journal of International Business Studies, 38, 573-577.

Luo Y. and R.L. Tung (2007), 'International Expansion of Emerging Market Enterprises: A Springboard Perspective', Journal of International Business Studies, 38(4), 481-498.

Matthews, J.A. (2006), 'Dragon Multinationals: New Players in the 21st Century Globalization', Asia Pacific Journal of Management, 23, 5-27.

MOFCOM (2008), Statistical Bulletin of China's Outward Foreign Direct Investment at

www.mofcom.gov.cn

Nicolas, F. (2009), 'Facts and Fallacies about Chinese Direct Investment in Europe', Chatham Hourse Briefing Paper, June.

Nicolas, F. and S. Thomsen (2008), 'The Rise of Chinese Firms in Europe: Motives, Strategies and Implications', paper presented at a Research Workshop on Chinese Investment in Europe, Chatham House, London, 17 September 2008. 
Niosi, J. and F.T. Tschang (2009), 'The Strategies of Chinese and Indian Software Multinationals: Implications for Internationalization Theory', Industrial and Corporate Change, 18(2), 269-294.

Nolan, P. (2001), China and the Global Economy. Palgrave Macmillan: London.

OECD (2006), Emerging Multinationals: Who are They? What do They do? What is at Stake?, OECD: Paris.

OECD (2008), OECD Investment Policy Review: China 2008, OECD: Paris.

Pack, H. (2001), 'The Role of Acquisition of Foreign Technology in Taiwanese Growth', Industrial and Corporate Change, 10(3), 713-734.

Poncet, S. (2007), 'Inward and Outward FDI in China', in Greenaway D., Milner C. and S. Yao (Eds) China and the World Economy: consequences and challenges, Palgrave: Londres, UK.

Rabellotti, R. and M. Sanfilippo (2008), 'Chinese FDI in Italy', paper presented at a Research Workshop on Chinese Investment in Europe, Chatham House, London, 17 September 2008.

Schuller, M. and A. Turner (2005), 'Global Ambitions: Chinese Companies Spread their Wings', China Aktuell-Journal of Current Chinese Affairs, 4, 3-14.

Spinarelli, M. (2009), 'Le multinazionali dei paesi emergenti: gli investimenti cinesi in Italia', Economia e Politica Industriale, 2, 131-159.

Tseng, C. S. (1994), 'The Process of Internationalization of PRC Multinationals' in Schultte, H. (Ed.) The Global Competitiveness of the Asian Firm. Macmillan: Basingstoke, UK:

UNCTAD (2008) World Investment Report. Geneva at www.unctad.org.

UNCTAD (2007) World Investment Report. Geneva at www.unctad.org.

UNCTAD (2006) World Investment Report. Geneva at www.unctad.org.

UNCTAD (2004) World Investment Report. Geneva at www.unctad.org.

Wang, L. and A. Szirmai (2008), 'Productivity Growth and Structural Change in Chinese Manufacturing', Industrial and Corporate Change, 17(4), 841-874.

Warner, M., H.N. Sek and X. Xiaojun (2004), 'Late Development Experience and the Evolution of Transnational Firms in the People's Republic of China', Asia Pacific Business Review ,10, 324.345.

Wu, F. (2005), 'The Globalization of Corporate China', The National Bureau of Asian Research, 16(3), 1-29.

Yeung, H. W. and W. Liu (2008), 'Globalizing China: The Rise of Mainland Chinese Firms in the Global Economy', Eurasian Geography and Economics, 49 (1), forthcoming.

Yiu, D.W., C.M. Lau and G.D. Bruton (2007), 'International Venturing by Emerging Economy Firms: the Effects of Firm Capabilities, Home Country Networks, and Corporate Entrepreneurship', Journal of International Business Studies, 38(4), 519-540.

Zhang, Y, (2005), 'China Goes Global', The Foreign Policy Centre: London.

Zhang, K. (2005), 'The Why, Where and How of Chinese Companies Outward Investment Intentions', Asia Pacific Foundation of Canada, 5, 1-36. 